\title{
The Utilization of Facebook as a Social Media Platform to Counter the Propagation of Intolerant Values among Youth of Desa Ciasmara Bogor-West Java
}

\author{
Agnes Setyowati Hariningsih. \\ Faculty of Social Sciences and Humanities, Universitas Pakuan, Indonesia \\ \{agnessetyowati@unpak.ac.id.\}
}

\begin{abstract}
Recent studies and surveys revealed that Bogor has ranked one of the most intolerant cities in Indonesia. Intolerant actions were reported to have been committed for the past few years. It relates to the bigger discourse on related issues in Indonesia. After the downfall of Soeharto's New Order regime, the growth of radical ideologies is increasing and intolerant actions were reported to have been committed in many parts of the country. In the contemporary Indonesia, the advancement of information technology has enabled the propagation of intolerant values, specifically among youth. As an internet-based social media platform, facebook plays an important role in the circulation of intolerant values. This research will focus on how intolerance-related facebook contents shape intolerant attitudes of the youth in Desa Ciasmara, Bogor. The random sampling method as well as ethnography (in-depth interview) were utilized to measure to what extent intolerance has been practiced by the youth of Desa Ciasmara. This study also applies cultural studies perspective to critically unearth and highlight the complexities of intolerance and radicalism in Indonesia. The finding posits that the youth of Desa Ciasmara were less tolerant in terms of interacting with friends of different religion. The related contents that they access in facebook have influenced to shape their less intolerant attitudes, but at the same time this social media platform has the potential to counter-radicalize. This study also offers the possible strategies that can be developed to curb the growth intolerance and radicalism among the youth of Desa Ciasmara by using social media platform.
\end{abstract}

Keywords: Bogor; facebook; Intolerance; Radicalism; Youth; Desa Ciasmara

\section{Introduction}

Intolerance has been one of the national problems in Indonesia after the downfall of the Soeharto's New Order regime. Simultaneously, other similar problems such as radicalism and terrorism are also growing. Recent studies revealed that people in some parts of Indonesia were reported to have committed intolerant actions, in terms of religious freedom and minority groups. 
The growing discourse of intolerance and radicalism can be portrayed within two ways. First, in a global sense, the tragedy of World Trade Center 9/11can serve as one the chief factors that triggers the growth of radical ideologies in many parts of the world, including in Indonesia. Second of all, in the national context, the downfall of Soeharto in 1998 has brought the issues to the surface. Politically, the reform era launched has brought dramatic changes, such as freedom of press, the revocation of state-sanctions against ethnic minorities, and subordination of military to civil authority known as democracy [1].

Under Soeharto regime, all kinds of ideologies were not given any opportunity to develop. Therefore, hijab was banned in schools between 1970s and 1980s [2]. The reform era was the crucial turning point for the repressed community to come out to the surface. In this critical phase, there was a loose in the center as a thirty two totalitarian government ended [3]. By using democracy and the loose in the center, many parties, including conservative Muslim mass organization, are trying to express and promote their ideology and obsessed to dominate the country [4].

After 1998, the growth of intolerance and radicalism has long been proven by studies and surveys. In 2016, PEW research center reported that Indonesian majority are intolerant to differing religions and minority groups [5]. Some restrictions on religion were also identified in several areas. In addition, another indication is that they are not welcome to minority religions not coo-opted and acknowledged officially by Indonesian government. For example, few years ago mainstream Muslim mass organizations were reported to have proclaimed their protest and resistance to Ahmadiyah adherents. Surprisingly, the protest was supported by the government [6]. In addition, in terms of religious intolerance a sadistic murder towards three Ahmadiyah adherents occurred in Cikeusik, Banten in 2011. It was committed by an Islamic mass organization[7]. Human Rights advocacy group Setara Institute for Democracy and Peace in 2018 revealed that cities in Indonesia such as Tanjungbalai, Banda Aceh, Jakarta, Bogor, Cilegon, Padang, Depok, Makassar, Medan, and Sabang were reported to be have ranked the worst in terms of intolerance[8].

Referring to the previous surveys, Bogor has ranked as one of the most intolerant cities in Indonesia. The label was given because the people were reported to have committed intolerant actions, such as protest against Shiites belief and the case of Gereja Kristen Indonesia (GKI) in Taman Yasmin Bogor where the Bogor administration officially sealed the church building so that the congregation had to be held outside the building.

Few studies and surveys also noted that discourses of intolerance have been infiltrated in educational institutions and targeted school students. Research by Indonesia's National Counterterrorism Agency (BNPT) in 2017 showed that college students had been influenced by radical ideologies. In the survey conducted in 15 provinces in Indonesia, 39 percent of the students were interested in joining radical ideologies and changing the state ideology with sharia. Similar study by Setara Institute also revealed that most students from some reputable universities were exposed to radical ideologies such as Ikhwanul Muslimin (Muslim Brotherhood), Salafi Wahabi, and Hizbut Tahrir. The data collected also showed that not only the students, but also the lecturers as well as the university offices were identified to have been exposed to radicalism [9], [10], [11].

The Center for the Study of Islam and Society in Collaboration with Syarif Hidayatullah State Islamic University in the late 2017 revealed that around 20 percent of school and university students in thirty four provinces in Indonesia are intolerant in terms of religious freedom [9], [10], [11]. Moreover, the similar study conducted by Mata Air Foundation and Alvara Research Center in November 2017 also found twenty percent of students in Indonesia is in favor of and agree with the idea of Caliphate. Briefly, it can be concluded that the 
government must give serious attentions to these educational institutions as schools and universities are the ideal sites that are susceptible to the spread of intolerant and radical ideologies.

The advancement of information and technology are celebrated by the people, especially the youth. Most of whom share their activities in social media. The most popular social media platform in Indonesia is facebook. Based on We Are Social report in 2019 it ranks the second popular social network after YouTube [12]. Referring to this, it is important to note that social media is not just a neutral platform, yet it serves as a medium for ideological contestation. Akmaliah (2018) argued that social media is used for the spread of political interests that often commodify certain ideological contents for certain purpose. He then implied that the utilization of social media can bring significant influence to the society [13].

This research will identify to what extent intolerant values have been propagated among the youth of Desa Ciasamara through social media Facebook. Moreover, this study is also trying to analyze how facebook shapes and influences their understanding about tolerance. Later, the study will offer the utilization of Facebook as a virtual space to curb intolerance and radicalism.

\section{Method}

The research was conducted in Desa Ciasmara, West Java starting from March until August 2019. The majority are one hundred percent Muslims and working as farmers. They embrace Islam practiced by Nahdatul Ulama and Muhammdiyah. Students aged fifteen and thirteen living and studying at schools in Desa Ciasmara, Pamijahan sub district-Bogor-West Java, were taken as the population in this research. There are about 1.457 young people of the whole population in this area.

Probability random sampling is also used in this research. According to Neuman [14], 10 percent of the population that is more than 1000 people and less than 10.000 people can represent the whole population. Of 1.457 people taken as general population, 1457 people were taken as target population and 146 people were taken as samples in this research. The data collection is divided into ways. Primary data were collected through survey and in depth interview with the respondents while secondary data were collected from any relevant sources such as journals, reports, books, online news, and academic studies.

Students from four different schools, both from regular and Islamic based schools, were taken to measure how intolerant and radical views have been practiced among youth in Desa Ciasmara. Islamic based schools apply $70 \%$ of national curriculum and $30 \%$ of religious knowledge while regular schools apply the entire national curriculum. The schools taken are MTSM Ciasmara (junior high school), SMAM Pamijahan (senior high school), SMP PGRI Ciasmara (junior high school), and SMK Bumi Putra (vocational high school). The respondents are 35 students from MTSM Ciasmara (24,6 percent), 37 students of SMAM Pamijahan (26,1 percent), 39 students of SMK Bumi Putra (27,5 percent), and 31 students of SMP PGRI Ciasmara (21,8 percent). The total respondents are 142 students from four different schools.

The issue intolerance is limited to the youth's attitudes toward friends from different religions. The intolerant practice will be identified from how youth reacts to interaction with friends from different religions and religious related contents they access facebook. The quantitative data will be analyzed and interpreted using theories, concepts, and relevant previous studies. The cultural studies perspective is also utilized to see the contesting 
discourses on intolerance and its circulation among youth in Indonesia, specifically in Bogor. One of the cultural studies' characteristics is to critically reveal how a culture is constructed through certain hegemony and power to maintain power and interests [15]. In this research, it is utilized to see how intolerance is constructed and disseminated to the youth and also elaborate the complexities of the discourse as well as verify the previous studies on intolerance in Bogor.

\section{Results and Discussion}

Intolerant Aspects of the Youth in Desa Ciasmara. In general, attitude refers to an individual tendency based on emotional evaluation towards an object. This research will mainly focus on the youth's attitudes of Desa Ciasmara towards social interactions with friends from different religions and ethnicity as well as the frequency of internet access to consume religious related contents in social media facebook.

It is also important to note that people living in the rural area collectively embrace the same certain religion. It is somehow problematic as it always deals with the local principles. It is difficult for them to tolerate things contradicting to their principles, such as making friends and choosing a leader of school organization. The following table will explain the youth's attitudes towards interactions with friends from different religions.

Table 1. YOUTH'S ATTITUDES towards INTERACTIONS with FRIENDS from DIFFERENT RELIGIONS

\begin{tabular}{lccccc}
\hline \multirow{2}{*}{ Types of School } & \multicolumn{4}{c}{ Interactional Aspects with Friends from Different Religions } \\
\cline { 2 - 6 } & $\begin{array}{c}\text { Hanging } \\
\text { Out }\end{array}$ & $\begin{array}{c}\text { Looking in } \\
\text { on Sick } \\
\text { Friends }\end{array}$ & $\begin{array}{c}\text { Choosing the leader } \\
\text { Of School } \\
\text { Organization }\end{array}$ & $\begin{array}{c}\text { Having a } \\
\text { Discussion }\end{array}$ & $\begin{array}{c}\text { Accepting } \\
\text { Oppinions }\end{array}$ \\
\hline Total of schools & 2.61 & 2.95 & 2.53 & 3.07 & 2.83 \\
Religion Based School & 2.63 & 3.00 & 2.46 & 2.96 & 2.76 \\
National Based School & 2.69 & 2.98 & 2.61 & 3.18 & 2.92 \\
Religion based Junior High & 2.39 & 2.86 & 2.45 & 3.09 & 2.67 \\
Religion based Senior High & 2.79 & 3.03 & 2.59 & 3.05 & 2.97 \\
National based Junior High & 2.39 & 2.84 & 2.52 & 3.29 & 2.74 \\
National based Senior High & 2.74 & 2.95 & 2.67 & 3.10 & 3.03 \\
\hline Remarks* tolerant*** quite tolerant; *** less tolerant**** almost intolerant
\end{tabular}

The youth's attitude is the tendency of how they interact with friends from different religions. It limited to several aspects such as hanging out with friends, looking in on sick friends, choosing the leader of school organization, and accepting opinions. Based on table, it can be concluded that in general the youth of Desa Ciasmara are tolerant, but they have the potential of being intolerant in terms of hanging out with friends from different religions, choosing the leader of school organization, and sharing or accepting opinions. At the same time, they become quite tolerant in terms of looking in on sick friends and having a discussion with friends from different religions. The finding posits that the youth of Desa Ciasmara have the tendency of being intolerant in terms of decision-making aspects.

Theoretically, Brofenbrenner argued that main factors such as parents, peers, and massmedia potentially contribute to shape their attitude [16]. Most notably, in the context of youth peers are the most important factors that play an integral role in constructing ideas or youth's attitude towards a specific object. It is also important to analyze factors that could potentially 
internalize intolerant values to the youth. As argued by Brofenrenner, factors such as parents, peers, and mass-media have the potential to significantly influence and shape the youth's attitudes. The research finds that parents and peers hold significantly important role in constructing tolerant attitude among youth in Desa Ciasmara.

Generally, students of regular based schools are more tolerant that those of Islamic based schools. Nevertheless, there are several aspects showing that students of national based schools are prone to be intolerant such as hanging out with friends and choosing a leader of school organization. In line with this, students of Islamic based schools are prone to be intolerant in terms of hanging out with friends, accepting opinions, and choosing a leader of school organization. Based on in depth interview with one of the school teachers, it cannot be separated from the national political issues. The case of blasphemy allegedly committed by the former governor of Jakarta, Basuki Tjahja Purnama in 2017 has influenced the youth's attitudes. They have open access to consume and interpret the news. In addition, the political situation escalates the tense so that the religion narrations are raised in the purpose of gaining voices to support one of the president candidates. This can also be evidenced by one of the trending hashtag \#2019gantipresiden painting in the village gate located few kilometers from Desa Ciasmara. Besides that, there is gravity of habib Rizieq, the leader of Islamic Defender Front by the pavement located few kilometers from Desa Ciasmara.

The Youth of Desa Ciasmara and Social Media Facebook. Next, this study will focus more on how the use of Facebook correlates to the spread of intolerance amongst youth. The youth of Desa Ciasmara have access to internet and spend more time using social media. Similar to offline space, social media is about relations and networking[17]. Users would be clustered based on their age, interests, and other social and cultural commonalties. This study finds that 97.1 percent of the Youth own smart phone are from one of the villages that still practice the conservative teachings of Islam (also known as 'anti-loud speaker' people). They are neither using cell phone nor watching television as both activities, according to their belief, are strictly prohibited by their parents. They also believe that technology such as cell phone and television brings more harm than good. They use their cell phone merely for simple communication (texts and calls). The possession of Smartphone and cell phone among youth automatically affects the high frequency of internet use. The data showed that 92.96 percent of the youth have an open access to internet. The 7.04 percent of them, who intentionally do not access internet, are those who refuse technology.

Based on the field research, they use their Smartphone to access their social media. Facebook is the most frequently used social media platform. They use it as a virtual space to find religious contents such as hijab tutorial and religious teachings from Islamic clerics. Besides that, they also use it to communicate with their school friends, upload photos, and talk about their school activities. There are two main reasons of high frequency of using Facebook. Firstly, the schools utilized it to keep the students informed and up-to-date with the school activities. The finding showed that 50.75 percent of them check their facebook account when they have internet access. It becomes the most popular social media platform as it provides simple features that facilitate them to communicate with other friends and find religious related contents.

In this research, facebook contents are limited specifically to religious contents. This serves as an attempt to find the correlation with the reason why they become less intolerant to friends of different religions. The study found that the concept of hijrah (individual Muslim shift towards a more religious way of life) ranks as the most popular content among them. The popularity of hijrah concepts among youth of Desa Ciasmara is caused by the presence of social media Islamic clerics such as ustad Abdul Somad, ustad Hanan Attaki, ustad Maulana, 
ustad Mansyur, and habib Bahar (also known as habib bule). Habib Bahar ranks as the most popular clerics whose related contents are mostly consumed. Additionally, it is interesting to note that few names of those Islamic clerics such as habib Bahar bin Ali Smith, ustad Abdul Somad, and habib rizieq were reported to allegedly have committed hate speech and blasphemy.

Habib Bahar Smith (also known as habib bule) was reported to have committed hate speech related to race and ethnicity. Besides that Ustad Abdul Somad was also reported to have committed blasphemy. In his recorded sermon, he provocatively said that Christian cross as "an element of the devil". Meanwhile, the FPI leader was criticized by several Human Rights activists for his provocative sermon that potentially threaten the state's unity [18].

The youth actively accessed contents related to them in social media. It can be said that the contents play an integral role in influencing and constructing their behavior ad interaction towards friends of different religion. Hariningsih (2018) argued that the social media contents contribute to shape an individual perspective [19]. In her study, people can become intolerant as well as radical after being exposed to certain contents in social media. In this sense, social media have been used to propagate certain discourses to shape public opinion. Additionaly, Facebook, as a virtual space, is utilized to spread certain teachings of Islam. In other words, this social media platform (like in offline space) serves as the arena of discourse contestations. In this study, those clerics' religious contents would potentially influence how the youth interacts with friends of different religion.

Referring to the finding, facebook can serve as a virtual space has the potential of preventing the growth of intolerance in Desa Ciasmara. Though contents of Islamic clerics such as habib Bahar Smith, ustad Abdul Somad, and habib Rizied have influenced the youth's behavior, they are still normally tolerant in some aspects. In other words, it implies that intolerance can possibly still be prevented by propagating the challenging discourses such as nationalism and moderate Islam or Islam nusantara discourse. Though it needs further studies to see the effectiveness of utilization of social media facebook in countering as well as preventing the growth of intolerant values, at least it has already been used to give various knowledge that they can reflect. As elaborated by Hariningsih [19], the radical groups often utilized Facebook to promote their ideology or Islam of their version so that the same attempt must be done in the purpose of challenging certain ideologies that could potentially lead to radicalism and threaten the national stability.

\section{Conclusions}

As part of Bogor, The youth of Desa Ciasmara is liable to become less intolerant in some aspects, such as interacting with friends from different religions. Besides that, they have accessed some religious contents through internet through social media, specifically facebook. The finding also revealed that they frequently accessed and consumed religious related contents about some Islamic clerics, such as habib Bahar Smith, ustad Abdul Somad, and habib rizieq, that are allegedly active in voicing resistance to the government, giving conservative sermons and hate speech on race and ethnicity. As a virtual space facebook can serve as the main source of information for the youth of Desa Ciasmara, this research offers the same strategies to propagate the countering discourse to prevent the growth of intolerant values in social media. Facebook can act as the virtual space where everyone has the privilege and authority to spread certain ideologies. It is very important as the youth will consume and be exposed to more knowledge on intolerant values that could lead to radicalism and threaten 
the national stability. Most notably, social actors (parents, school teachers, friends and so forth must also take part to propagate the nationalism as well as moderate Islamic teachings to the youth of Desa Ciasmara. By utilizing facebook, the youth could not only actively consume religious related contents that promote nationalism, but produce or (re)share them to challenge certain ideologies.

\section{References}

[1] \& T. C. H. Hodri Ariev, Ratno Lukito, The Illusion of an Islamic State: The Expansion of Transnational Islamic Movements in Indonesia. Jakarta, Indonesia: The Wahid Institute, 2009.

[2] H. Abdurakhman, Islam Untuk Indonesia. Bandung, Indonesia: Nuansa Cendikia, 2017.

[3] A. Kusno, Ruang Publik, Identitas dan Memori Kolektif Jakarta: Pasca Suharto. Yogyakarta: Penerbit Ombak, 2009.

[4] M. Budiman, "Treading the Path of the Sharia: Indonesian Feminism at the Crossroads of Western Modernity and Islamism," J. Indones. Sci. Humanit., vol. Volume 1, pp. 73-93, 2008.

[5] PEW Research Center, "Global Uptick in Government Restrictions on Religion in 2016," 2016.

[6] Muyazzin Ahyar, "Ahmadiyah dalam Labirin Syariah dan Nasionalisme Ketuhanan di Indonesia.," J. Pemikir. Huk. Islam, vol. 14 (2), pp. 110-118, 2015.

[7] A. N. Burhani, Menemani Minoritas: Paradigma Islam Tentang Keberpihakan dan Pembelaan Kepada yang Lemah. Jakarta, Indonesia: PT Gramedia Pustaka Utama, 2019.

[8] S. Institute, "Press Release: Indeks Kota Toleran (IKT) Tahun 2018," Jakarta, Indonesia, 2018.

[9] B. Agung, "BNPT dan Eksakta di 7 PTN Terpapar Radikalisme.," 2018.

[10] "Nearly 6 in 10 Indonesian Muslim Teachers Intolerant: Many Vilify Modern Science," Jakarta Globe, 2018.

[11] D. Siregar, "Ini Kampus-Kampus Markas Besar Kelompok Radikal," Geotimes, 2019.

[12] A. D. Riyanto, "Hootsuite (We are Social):Indonesian Digital Report 2019."

[13] W. Akhmaliah, "Bukan Sekedar Penggaung (Buzzers): Media Sosial dan Transformasi Arena Politik," J. Maarif, vol. 13(1). 9-2, 2018.

[14] L. Neuman, Social Research Methods: Quantitative and Qualitative Approaches. Boston, United States: Allyn and Bacon, 1997.

[15] B. Chris, Cultural Studies Theory and Practice. London: SAGE Publication Ltd, 2000.

[16] U. \& M. P. A. Bronfenbrenner, The Ecology of Developmental Process. In W. Damon (Series Ed.) \& RM Learner (Vol Ed.) Handbook of Child Psychology: Vol 1. New York: 'Wiley, 1986.

[17] M. Lim, "Many Clicks but Little Sticks: Social Media Activism in Indonesia.," J. Contemp. Asia., vol. 43(4), 636, 2013.

[18] J. Post, "Police Drop Porn Case against Rizieq."

[19] A. S. Hariningsih, "The Women's Strategy in Preventing Radicalism: Case Study of Muslim Women in Bogor," pp. 88-102, 2018. 